\title{
A meta-analysis of the effects of preweaned calf nutrition and growth on first-lactation performance ${ }^{1}$
}

\author{
S. L. Gelsinger, A. J. Heinrichs, ${ }^{2}$ and C. M. Jones \\ Department of Animal Science, The Pennsylvania State University, 324 Henning Building, University Park 16802
}

\begin{abstract}
Several studies and a 2013 meta-analysis have proposed that increased feeding of milk or milk replacer to neonatal calves may improve subsequent milk production. However, data from individual studies are conflicting, and the meta-analysis was unable to assess the influence of calf starter intake. The objective of the current meta-analysis was to review newly published data and evaluate the effects of preweaning diet (including calf starter intake) and growth rate on first-lactation milk, fat, and protein yield. Data from 9 studies representing 21 treatment groups were included in the analysis. We created separate models for each outcome variable using regression methods in SAS (version 9.4, SAS Institute Inc., Cary, NC) to determine the effects of intake and growth rate. We then selected the best-fitting models using Akaike's information criterion. The effect of study explained 98, 85, and $96 \%$ of the variance in 305-d milk, fat, and protein yield in first lactation, respectively, indicating that other aspects of management are more important for determining first-lactation production than preweaning intake and growth rate. However, we found a synergistic relationship between preweaning liquid and starter dry matter intake for improving milk, fat, and protein production, and a positive relationship between firstlactation performance and preweaning average daily gain. These data indicate that provision of adequate nutrients from liquid and solid feeds and maintaining average daily gain above $0.5 \mathrm{~kg} / \mathrm{d}$ can enhance the firstlactation performance of heifers when combined with proper postweaning practices.
\end{abstract}

Key words: meta-analysis, first-lactation, average daily gain, preweaned calf management

\footnotetext{
Received December 10, 2015.

Accepted April 9, 2016.

${ }^{1}$ This research is a component of NC-2042: Management Systems to Improve the Economic and Environmental Sustainability of Dairy Enterprises.

${ }^{2}$ Corresponding author: ajh@psu.edu
}

\section{INTRODUCTION}

In recent years, there has been much interest in the effects of preweaned calf management on subsequent lactation performance, but results from studies investigating this relationship are variable. In some studies (Shamay et al., 2005; Moallem et al., 2010; Soberon et al., 2012), intensive feeding of milk or milk replacer to neonatal calves improved subsequent milk production. A 2013 symposium (Soberon and Van Amburgh, 2013) reported a $42.9-\mathrm{kg}$ increase in milk production with each $100 \mathrm{~g} / \mathrm{d}$ increase in nutrient intake from milk or milk replacer. However, other studies (Raeth-Knight et al., 2009; Davis Rinker et al., 2011; Kiezebrink et al., 2015) have been unable to detect differences in milk, fat, and protein production when calves received higher volumes of milk or milk replacer, or milk replacers with greater nutrient densities.

Growth rate of heifers postweaning through puberty has been shown to be quadratically related to milk yield, with maximum production occurring in heifers grown at $799 \mathrm{~g} / \mathrm{d}$ (Zanton and Heinrichs, 2005). Data from Brown et al. (2005) imply that rapid growth rate in the first $3 \mathrm{mo}$ of life influences mammary development differently compared with rapid growth rate postweaning. It is clear that intensive feeding of milk or milk replacer to neonatal calves increases growth rate, resulting in greater BW and size at weaning (Jasper and Weary, 2002; Cowles et al., 2006; Stamey et al., 2012). Soberon and Van Amburgh (2013) reported that increasing preweaning ADG also increases subsequent milk production, but this relationship is not as clearly defined as the relationship between postweaning growth rate and milk production.

An observational study of 795 Holstein calves through 16 wk of age indicated that increasing DMI at weaning and reducing the number of sick days could also increase first-lactation milk production (Heinrichs and Heinrichs, 2011). Although intensive feeding of milk or milk replacer increases ADG, it can also decrease starter intake and often increases the number of days with greater fecal fluidity (Cowles et al., 2006; Davis Rinker et al., 2011; Stamey et al., 2012). Using step-down 
weaning protocols can encourage starter consumption in intensively fed calves and alleviate postweaning weight loss (Khan et al., 2007; Sweeney et al., 2010), but effects on health may be more complicated to resolve. In addition to greater fecal fluidity, Foote et al. (2007) reported a lower percentage of CD4+ T-cells and reduced the viability of T-cells and antigen response in calves fed to achieve a high rate of gain before weaning. These data imply that intensive feeding of milk or milk replacer to calves preweaning may have negative effects on subsequent lactation performance.

Multiple sources of variation occur in a heifer's life between weaning and calving, making it difficult to detect the effects of preweaning calf management on milk production in the first lactation. The meta-analysis conducted in 2013 (Soberon and Van Amburgh, 2013) compiled results from several data sets and reported a $42.9-\mathrm{kg}$ increase in first-lactation milk production with every $100 \mathrm{~g} / \mathrm{d}$ increase in nutrient intake from liquid feed or a $155-\mathrm{kg}$ increase for every $100 \mathrm{~g} / \mathrm{d}$ increase in preweaning growth rate. However, not all data sets used in that analysis were published, leaving questions about the validity of the results. Since the 2013 meta-analysis, additional studies have been published that include data on calf starter intake. The objective of the current analysis was to incorporate newly published data and evaluate the effects of preweaning diet (including calf starter intake) and growth rate on first-lactation milk, fat, and protein yield.

\section{MATERIALS AND METHODS}

\section{Study Selection}

A literature search was conducted using PubMed, CABI, and Web of Knowledge databases to compile all published studies that related preweaned calf management to subsequent first-lactation performance. We selected search terms based on the titles of known eligible published studies. Articles resulting from the original search included terms in their titles that described preweaning management ("nursing," "suckl*," "preweaning," "prior to weaning," "feeding level," "enhance*," "intens*," or "growth") and lactation ("performance," "production," "first lactation," "yield," or "productivity"). Articles were also required to include the terms "cow," "calf," or "calves," along with "milk" or "lactation," and could not include "beef," "veal," "growth hormone," or "buffalo."

Following the initial search, we reviewed individual titles and abstracts to remove irrelevant studies. Studies selected for inclusion were those with an adequate description of preweaning treatments, including com- plete descriptions of all feedstuffs offered to calves; individual measurements of intake for all feedstuffs and growth during the entire preweaning period; and milk production in the first lactation. Articles must have been written in English and published since 1980, both to limit variability in production responses due to differences in animal management and genetics, and to allow results to more accurately reflect current industry practices. Following the review of abstracts, 11 studies were selected for the meta-analysis. Data compiled from each study included preweaning daily DMI of milk or milk replacer, starter grain, and hay; preweaning ADG; total 305-d milk, fat, and protein production; and respective standard errors.

A summary of the 9 studies included in the final analysis is given in Table 1 . The age at which calves were weaned ranged from 42 to $84 \mathrm{~d}$, with a mean of 60 d. To include all lengths of preweaning periods, intake and growth variables were included as rates per day. Changes in milk, fat, and protein production due to liquid or starter DMI or ADG were reported per 100 $\mathrm{g} / \mathrm{d}$ increase in intake or growth rate. These units were chosen to allow realistic goals for preweaning intake and growth, because it is often impossible to raise DMI or ADG by 1 or more $\mathrm{kg} / \mathrm{d}$.

Soberon et al. (2012) did not report starter consumption and milk replacer treatments changed during the course of the study. That was an observational study in which treatments were assigned retrospectively, whereas other studies reported the results of controlled experiments. Bar-Peled et al. (1997) reported intake or growth measurements for only a portion of the preweaning period. Data from these 2 studies were not included in the final analysis.

Raeth-Knight et al. (2009) did not report ADG for the total preweaning period for calves that received the "intensive high-solids high-feeding" treatment; therefore, only intake and production data from this treatment were included in the analysis. Terré et al. (2009) did not report first-lactation fat or protein production; therefore, data from this study are represented only in the analysis of effects on 305-d milk yield. Two studies subdivided calf populations from each preweaning treatment to test the effect of prepubertal protein supplementation (Shamay et al., 2005; Moallem et al., 2010). They averaged lactation responses from supplemented and unsupplemented groups by preweaning treatment, and we used these averages in the current analysis. The study design of Morrison et al. (2009) included 2 feeding levels and 2 protein contents of milk replacer, but the authors reported means separately for each response variable by feeding level and protein content. Neither feeding level nor protein content affected 
lactation parameters. We used values from the high and low feeding levels in the current analysis.

One study reported fat-corrected milk without raw 305-d production (Margerison et al., 2013). In this case, we converted values using the relationship between fatcorrected milk and actual milk yield reported by Gaines and Davidson (1923):

$$
F C M=\frac{132.06(M)+4,964(F)}{330.62}
$$

where $M=$ actual milk yield, $F=$ actual fat yield, and $F C M=$ fat-corrected milk yield. Correction factors were determined and used to convert treatment mean FCM values to raw values. We used the same relationship to derive the following equation to estimate the standard error of raw milk production from the standard error of fat-corrected milk

$$
\operatorname{Var}(F C M)=0.16 \operatorname{Var}(M)+225 \operatorname{Var}(F)+12 \operatorname{Cov}(M F)
$$

Standard errors were calculated using the relationship between correlation (r), covariance (Cov), and standard deviation (SD), where

$$
r=\frac{\operatorname{Cov}(M, F)}{\operatorname{SD}(M) \times \operatorname{SD}(F)}
$$

and assuming a correlation between milk and fat yield of 0.8 (Van Vleck and Dong, 1988). One study reported only standardized mature-equivalent milk production without actual milk production (Raeth-Knight et al., 2009). In this case, values were derived using conversion factors from the Council on Dairy Cattle Breeding for first-lactation, Holstein heifers in Minnesota, with birth and calving dates within the range reported in the article (Raeth-Knight et al., 2009; Council on Dairy Cattle Breeding, 2015). We converted standard errors using the same factor.

\section{Statistical Analysis}

All analyses were conducted using SAS (Version 9.4, SAS Institute Inc., Cary, NC). We used Proc Univariate to extract descriptive statistics. We determined correlations between predictors using Proc Corr, and due to high correlation between liquid DMI and ADG $(r=0.5$; $P=0.02$ ), we created separate models to explore the effects of intake and growth rate on response variables. Dry matter intake from liquid and starter were also highly correlated ( $\mathrm{r}=-0.82 ; P<0.01$; Figure 1$)$; however, to determine the effects of each feedstuff given the other, both were forced into a single model. Plotting DMI from liquid against DMI from starter revealed no data points in the first and third quadrants, because no calves consumed large quantities of both liquid and starter feeds and all calves consumed some of both feeds. Therefore, the data were insufficient to test an interaction effect between liquid and starter intake, and only main effects for each were offered to the model.

Plotting ADG across outcome variables indicated a possible quadratic effect; therefore, ADG was offered to the model as both linear and squared terms. When the quadratic model explained a greater proportion of the variation in response, as indicated by Akaike's information criterion (AIC), we determined first-order derivatives with regard to ADG and used them to calculate the preweaning growth rate associated with minimum

\begin{tabular}{|c|c|c|}
\hline Study & Comparison & $\begin{array}{l}\text { Effect on first-lactation milk } \\
\text { production }^{1}\end{array}$ \\
\hline Castells et al., 2015 & Milk replacer with vs. without oat hay supplementation & No difference \\
\hline Davis Rinker et al., 2011 & Low vs. high milk replacer feeding rate & No difference \\
\hline Morrison et al., $2009^{2}$ & 5 vs. $10 \mathrm{~L} / \mathrm{d}$ of milk replacer & No difference \\
\hline Raeth-Knight et al., 2009 & Conventional milk replacer vs. various intensive feeding programs & No difference \\
\hline Terré et al., 2009 & Low vs. high milk replacer feeding rate & No difference \\
\hline Shamay et al., 2005 & Conventional milk replacer vs. whole milk & No difference \\
\hline
\end{tabular}
first-lactation performance.

Table 1. Summary of studies included in the final analysis

${ }^{1}$ Treatment effects declared at $P<0.05$.

${ }^{2}$ Authors also compared high and low milk replacer protein content, but data from the protein comparison were not included in the current analysis. 


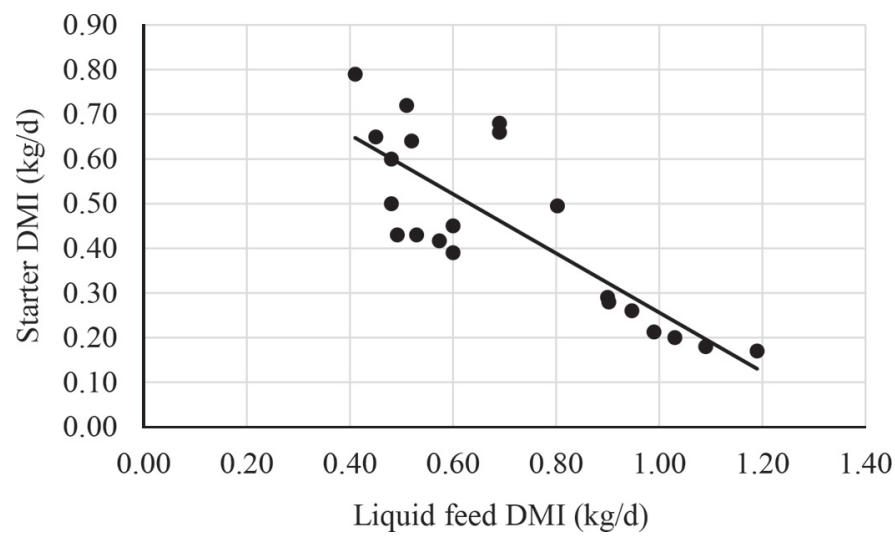

Figure 1. Relationship $(\mathrm{r}=-0.82 ; \mathrm{Y}=-0.66 \mathrm{X}+0.92)$ between daily DMI before weaning as liquid feed (milk or milk replacer) and as starter grain. Each data point represents 1 of 21 treatments from 9 individual studies comparing preweaned calf management with firstlactation performance.

Initial models were created in Proc Mixed, including study as a random effect as recommended by St. Pierre (2001). These models indicated that the effect of study explained a very large proportion of the variation in production response relative to the fixed effects of liquid or starter intake or ADG. In addition, single-factor and intercept-only models were not able to converge with a positive, definite Hessian matrix, resulting in uninterpretable model fitness parameters.

Squared correlation coefficients $\left(\mathrm{R}^{2}\right)$ were determined for the effect of study on each response variable using Proc GLM. The effect of study explained 98, 85, and $96 \%$ of the variance in 305-d milk, fat, and protein yield in the first lactation, respectively; therefore, we created subsequent models including study as a fixed effect. Individual treatment results from each study were weighted in the analysis using the inverse of the standard error associated with each response (St-Pierre, 2001).

Model selection was conducted in Proc Mixed. Models compared included the fixed effect of study only; study plus intake from liquid and starter, separately and combined; and study plus the linear effect of ADG, with and without the quadratic effect. We selected the best predictive models based on AIC rather than the $P$-values associated with each parameter, because the power of this analysis for hypothesis testing was low for reasons of small sample size $(\mathrm{n}=21)$ and small residual variation after accounting for the effect of study. In addition, $P$-values are most useful for comparing 2 hypotheses, assuming that one hypothesis is correct and the other is false; the goal of hypothesis testing is rejection of the false hypothesis (Anderson et al., 2000). The goal of this analysis was not to reject false hypotheses based on individual parameters, but to select the models that explained the greatest amount of variation. Akaike's information criterion does not determine significance; rather, it is an estimate of the amount of information unexplained by a given model (Anderson et al., 2000). This method has been reviewed by several biologists and shown to be highly efficient for selecting the most predictive models from a set of plausible options (Anderson et al., 2000; Burnham and Anderson, 2001; Aho et al., 2014). For these reasons, we determined the value of adding each parameter to the models based on changes in AIC rather than on traditional $P$-values.

\section{RESULTS AND DISCUSSION}

Of the 9 studies included in the analysis, 4 compared a conventional milk replacer program with various accelerated programs, 2 compared milk replacer with whole milk, 1 compared feeding different volumes of whole milk, and 2 tested the effects of dietary supplements added to milk or milk replacer (Table 1). The composition of liquid and starter diets varied between studies. Milk replacer fat and protein percentage ranged from 12 to $22 \%$ and 21 to $31 \%$, respectively. Sources of fat and protein were also variable. Starter $\mathrm{CP}$ content ranged from 18 to $25 \%$. All liquid and starter diets were treated equally for the purposes of this analysis, allowing for maximal use of the published data, but limiting interpretation of the results, because it is impossible to determine the proportion of the lactation response that is due to diet composition. Descriptive statistics for each variable of interest are presented in Table 2. Mean liquid and starter DMI from included studies ranged from 0.41 to $1.19 \mathrm{~kg} / \mathrm{d}$ and 0.17 to 0.79 $\mathrm{kg} / \mathrm{d}$, respectively; preweaning ADG ranged from 0.34 to $0.90 \mathrm{~kg} / \mathrm{d}$.

Parameter estimates and fitness characteristics for intake models are given in Table 3, including fitness characteristics for study-only models for each outcome variable. The majority of variation in each response was explained by study (clearly indicated by $\mathrm{R}^{2}$ values), implying that overall farm management has a much greater effect on first-lactation performance than nutrition and growth before weaning. Therefore, although increasing intake of liquid and starter feeds before weaning can enhance good postweaning management, their influence relative to other management practices is very small, and exact coefficients reported here should be applied with caution. The model that included study effect and both liquid and starter intakes explained the greatest amount of variation in each response, as evidenced by the greatly improved 
Table 2. Descriptive statistics: DMI from liquid ${ }^{1}$ or starter diets; preweaning ADG; and milk, fat, and protein yields in first lactation

\begin{tabular}{lccccc}
\hline Item & $\mathrm{n}^{2}$ & Mean & $\mathrm{SD}$ & Minimum & Maximum \\
\hline Liquid DMI (kg/d) & 21 & 0.71 & 0.24 & 0.41 & 1.19 \\
Starter DMI (kg/d) & 21 & 0.45 & 0.19 & 0.17 & 0.79 \\
ADG (kg/d) & 20 & 0.64 & 0.15 & 0.34 & 0.90 \\
305-d milk yield (kg) & 21 & 9,133 & 1,658 & 5,739 & 11,510 \\
Fat yield (kg) & 19 & 328 & 36 & 257 & 386 \\
Protein yield (kg) & 19 & 277 & 38 & 202 & 322 \\
\hline
\end{tabular}

${ }^{1}$ Milk or milk replacer.

${ }^{2}$ Number of treatments from eligible studies reporting the variable of interest and included in the analysis.

AIC value. Nevertheless, the greatest proportion of the variation was explained by study.

The models including study and either liquid or starter DMI were equivalent for predicting first-lactation milk, fat, and protein yield, but the directions of their effects were opposed. This was most likely due to a strong negative correlation between liquid and starter intakes $(\mathrm{r}=-0.82$; Figure 1$)$ because of calves' limited capacity for daily DMI. This relationship was especially clear when liquid feed DMI was greater than $0.8 \mathrm{~kg} / \mathrm{d}$. Starter DMI was more variable when liquid DMI was less than $0.8 \mathrm{~kg} / \mathrm{d}$. This increase in variability may have been due to the palatability or digestibility of the starter grains offered and may also have been affected by intake of other feedstuffs. The effects of grain type, form, and extent of processing - as well as the effect of supplemental forage on rumen development in young calves - have been extensively studied (Khan et al., 2008; Hill et al., 2009), and reviewed in detail (Khan et al., 2016). Of the 9 studies included in the current analysis, starter ingredients were available for 5 , and corn was the primary grain in 4 of those. The starter mix fed by Morrison et al. (2009) included 23\% barley and $20 \%$ beet pulp in addition to corn. Supplemental forage was offered to calves by Margerison et al. (2013) and in one treatment from Castells et al. (2015). Forage intake was not significant in either study, but it may explain some of the variability in starter intake.

Similar to the 42.9-kg increase in milk production predicted by Soberon and Van Amburgh (2013) for each additional $100 \mathrm{~g} / \mathrm{d}$ of DMI from liquid feed, the study plus liquid models reported here predicted increases of $66.2,3.5$, and $2.8 \mathrm{~kg}$ in milk, fat, and protein production during the first lactation, respectively. In contrast, models including only study and starter intake predicted reductions of 50.4, 2.5, and $2.1 \mathrm{~kg}$ for milk, fat, and protein production, respectively, in the first lactation for each $100 \mathrm{~g} / \mathrm{d}$ increase in starter DMI. It is important to remember that these models were limited because they represented neither the effect of

Table 3. Model fitness parameters for intake effects on 305-d milk, fat, and protein yields in first lactation

\begin{tabular}{|c|c|c|c|c|c|}
\hline Dependent variable $=$ Model & Intercept & $\begin{array}{l}\text { Liquid }^{1} \\
(P \text {-value })\end{array}$ & $\begin{array}{l}\text { Starter } \\
(P \text {-value })\end{array}$ & R-squared & $\mathrm{AIC}^{2}$ \\
\hline \multicolumn{6}{|l|}{$305-\mathrm{d}$ milk yield $(\mathrm{kg})=$} \\
\hline Study & 11,341 & & & 0.98 & 185.1 \\
\hline Study + liquid ${ }^{3}$ & 10,864 & $66.2(0.19)$ & & 0.98 & 169.0 \\
\hline Study + starter ${ }^{3}$ & 11,557 & & $-50.4(0.52)$ & 0.98 & 169.6 \\
\hline Study + liquid + starter $^{3}$ & 9,797 & $138.5(0.16)$ & $127.0(0.37)$ & 0.98 & 151.9 \\
\hline \multicolumn{6}{|l|}{ Fat yield $(\mathrm{kg})=$} \\
\hline Study & 305.0 & & & 0.85 & 103.5 \\
\hline Study + liquid & 280.0 & $3.5(0.19)$ & & 0.87 & 93.3 \\
\hline Study + starter & 315.7 & & $-2.5(0.54)$ & 0.86 & 93.9 \\
\hline Study + liquid + starter & 208.6 & $8.4(0.12)$ & $8.4(0.28)$ & 0.89 & 81.5 \\
\hline \multicolumn{6}{|l|}{ Protein yield $(\mathrm{kg})=$} \\
\hline Study & 295.9 & & & 0.96 & 92.3 \\
\hline Study + liquid & 276.0 & $2.8(0.10)$ & & 0.97 & 81.9 \\
\hline Study + starter & 304.7 & & $-2.1(0.48)$ & 0.97 & 83.2 \\
\hline Study + liquid + starter & 245.3 & $4.7(0.10)$ & $4.0(0.36)$ & 0.97 & 71.7 \\
\hline
\end{tabular}

${ }^{1}$ Milk or milk replacer.

${ }^{2}$ Akaike's information criterion; smaller values indicate less unexplained variance.

${ }^{3}$ Coefficients in models including liquid and starter represent the change in each lactation parameter given a $100 \mathrm{~g} / \mathrm{d}$ increase in liquid or starter DMI. 
Table 4. Model fitness parameters and coefficients ${ }^{1}$ for ADG effects on 305-d milk, fat, and protein yields in first lactation

\begin{tabular}{|c|c|c|c|c|c|}
\hline $\begin{array}{l}\text { Dependent variable }= \\
\text { Model }\end{array}$ & Intercept & $\begin{array}{c}\mathrm{ADG} \\
(P \text {-value })\end{array}$ & $\begin{array}{l}\text { ADG-squared } \\
(P \text {-value })\end{array}$ & R-squared & $\mathrm{AIC}^{2}$ \\
\hline \multicolumn{6}{|l|}{$305-\mathrm{d}$ milk yield $(\mathrm{kg})=$} \\
\hline Study + ADG & 10,461 & $130.4(0.26)$ & & 0.98 & 152.3 \\
\hline Study + ADG + ADG-squared & 12,198 & $-488.7(0.44)$ & $515.2(0.32)$ & 0.98 & 132.4 \\
\hline \multicolumn{6}{|l|}{ Fat yield $(\mathrm{kg})=$} \\
\hline Study + ADG & 264.2 & $6.1(0.31)$ & & 0.86 & 83.4 \\
\hline Study + ADG + ADG-squared & 344.5 & $-21.5(0.58)$ & $22.3(0.47)$ & 0.87 & 69.7 \\
\hline \multicolumn{6}{|l|}{ Protein yield $(\mathrm{kg})=$} \\
\hline Study $+\mathrm{ADG}$ & 264.1 & $4.7(0.23)$ & & 0.97 & 73.5 \\
\hline Study + ADG + ADG-squared & 329.5 & $-19.3(0.33)$ & $20.3(0.23)$ & 0.98 & 59.9 \\
\hline
\end{tabular}

${ }^{1}$ Coefficients represent the change in each lactation parameter given a $100 \mathrm{~g} / \mathrm{d}$ increase in ADG.

${ }^{2}$ Akaike's information criterion; smaller values indicate less unexplained variance.

overall preweaning nutrition nor the biology of the calf, which requires highly digestible nutrients for growth and fermentable carbohydrates for rumen development.

Heinrichs and Heinrichs (2011) showed that starter consumption at weaning had the greatest positive effect on first-lactation milk production, and it is clear that substantial starter consumption preweaning is necessary for calves to consume large quantities of starter at weaning and continue growth in the first few months of life (Cowles et al., 2006; Bach et al., 2013). Therefore, we surmised that the negative relationship shown here between starter intake and first-lactation production was indicative of the negative effects of limited nutrient availability for maximum tissue development, as discussed previously (Soberon and Van Amburgh, 2013) and an artifact of the negative correlation between liquid and starter intake. The importance of preweaning starter intake was clear when comparing the study and liquid model to the study, liquid, and starter intake model. This comparison was lacking in the previous meta-analysis, although it may have been represented indirectly in the analysis of growth rate on first-lactation milk production (Soberon and Van Amburgh, 2013). The model combining the effects of liquid and starter intake revealed a synergistic relationship between the feeds for milk, fat, and protein production. When liquid feeds were offered alongside starter, the model projected that milk, fat, and protein would increase by $138.5,8.4$, and $4.7 \mathrm{~kg}$, respectively. Likewise, calves that consumed at least $100 \mathrm{~g}$ of starter DM per day alongside their liquid diet preweaning were expected to produce $127.0 \mathrm{~kg}$ more milk, $8.4 \mathrm{~kg}$ more fat, and $4.0 \mathrm{~kg}$ more protein than calves that consumed no starter before weaning.

The synergistic relationship between liquid and starter intake was previously postulated in a review by Bach (2012). Although both liquid and starter must be consumed, the role of each feed is different in the preweaned calf. Liquid feeds are the predominant source of nutrients for growth and body development until the rumen is capable of digesting solid feeds, whereas starter consumption before weaning serves primarily to stimulate rumen development (Davis and Drackley, 1998). Thus, the model that used both liquid and starter intake to predict lactation performance simultaneously supported results indicating an effect of liquid feed and results of the long-term observational study, showing the major importance of starter intake at weaning (Heinrichs and Heinrichs, 2011).

Parameter estimates and fitness characteristics for growth models are given in Table 4 . In the meta-analysis by Soberon and Van Amburgh (2013), milk production was projected to increase by $155 \mathrm{~kg}$ for every additional $100 \mathrm{~g} / \mathrm{d}$ increase in ADG before weaning, and this relationship did not appear to plateau. Similarly, linear models from the current analysis estimated approximately 130.4-, 6.1-, and 4.7-kg increases in milk, fat, and protein production, respectively, for each additional $100 \mathrm{~g} / \mathrm{d}$ of ADG. However, greater variation in these responses was explained when a quadratic ADG term was included in the model, indicating that linear models are inadequate for describing the relationship between preweaning ADG and first-lactation production.

Milk yield responses and ADG from all treatments are shown by study in Figure 2, as well as the accompanying regression line of the quadratic relationship between ADG and milk production. Interestingly, the relationship between preweaning $\mathrm{ADG}$ and first-lactation production was inverted from the relationship reported for postweaning, prepubertal heifers (Zanton and Heinrichs, 2005). This is most likely due to different stages of mammary development in preweaned calves (Brown et al., 2005; Lohakare et al., 2012). Brown et al. (2005) reported differential effects on mammary development whether calves received more nutrient-dense feeds at 


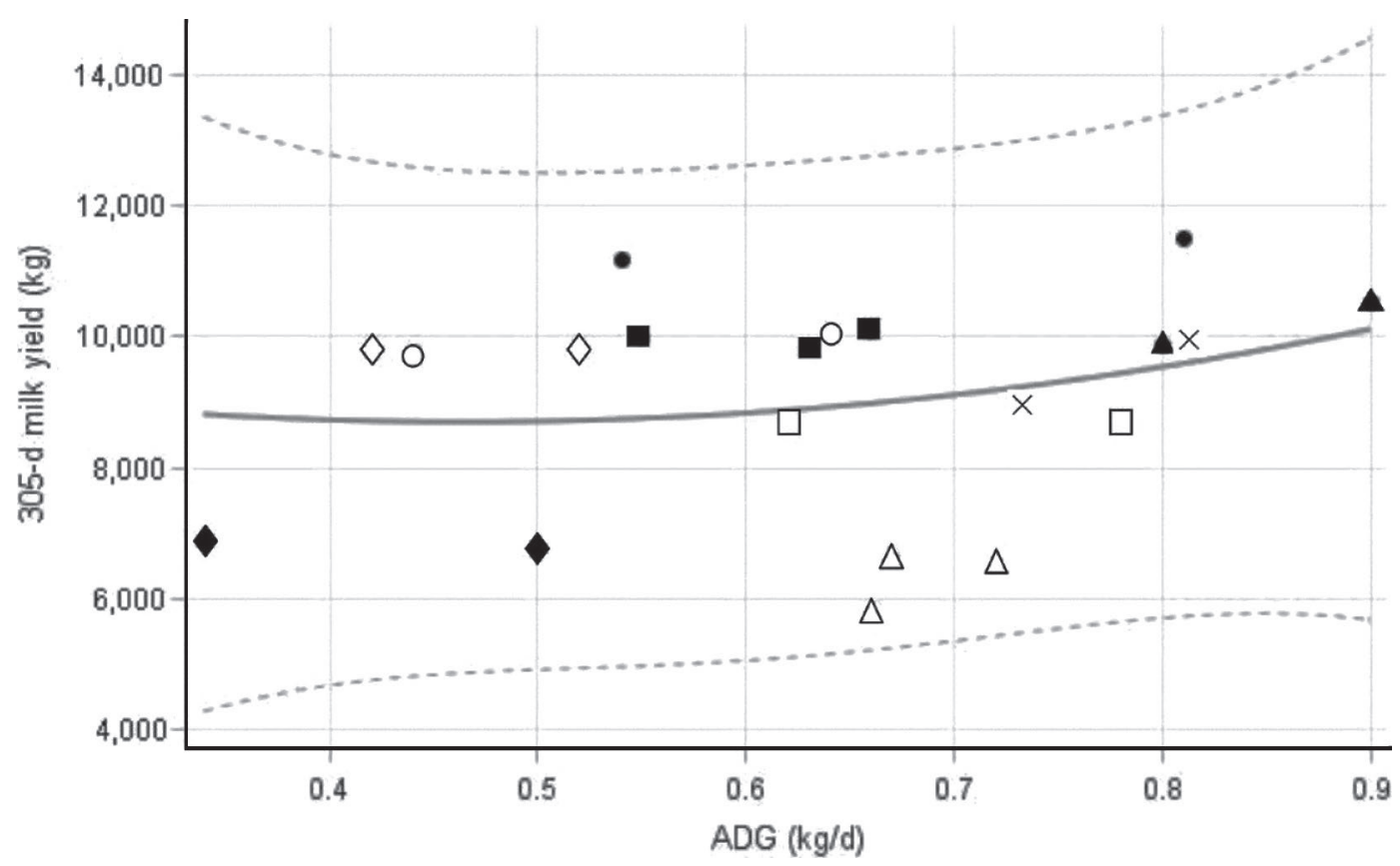

Figure 2. Mean milk production response to preweaning growth rates from treatments of experiments included in this meta-analysis. $\diamond=$ Castells et al., 2015; $\square=$ Kiezebrink et al., 2015; $\Delta=$ Margerison et al., 2013; $\bigcirc=$ Davis Rinker et al., 2011; $\times=$ Moallem et al., 2010; $=$ Morrison et al., 2009; $\mathbf{\square}=$ Raeth-Knight et al., 2009; $\boldsymbol{\Delta}=$ Terré et al., 2009; and $\boldsymbol{\bullet}=$ Shamay et al., 2005. The model of milk yield $=$ ADG + $\mathrm{ADG}^{2}$ is represented by the solid line, with $95 \%$ confidence limits shown by the dashed lines.

2 to 8 wk or 8 to 14 wk. Heifers that were fed a highprotein, low-fat milk replacer combined with a highprotein starter had greater total mammary gland mass and greater parenchymal mass, DNA, and RNA, but preweaning diet did not influence the percent fat accumulation in the mammary gland. In contrast, feeding a high-protein starter postweaning during wk 8 to 14 did not affect parenchymal mass, DNA, or RNA, but did increase the percent fat in the mammary gland (Brown et al., 2005). Thus, the greater milk responses from increased preweaning nutrient intake and ADG reported here may be a result of altered mammary development.

In the current analysis, heifers growing at rates of $0.5 \mathrm{~kg} / \mathrm{d}$ before weaning produced the least milk, fat, and protein in their first lactation. Based on observations shown in Figure 2, preweaning ADG seemed to minimally affect milk production when growth rate was below $0.5 \mathrm{~kg} / \mathrm{d}$, but had a greater influence as growth rate increased from 0.5 to $0.9 \mathrm{~kg} / \mathrm{d}$. This is most likely related to the positive effect of preweaning intake on subsequent production, as calves that consume more nutrients will experience faster growth and greater nutrient availability, and this may be related to degree of mammary development. Faster growth may also be indicative of metabolic efficiency, implying that metabolically efficient calves continue to be metabolically efficient as adults (Sejrsen et al., 2000).
Confidence limits for the effect of ADG on milk yield are indicated in Figure 2 by the dashed lines. Although the AIC values in Table 4 indicate that the greatest amount of variation is explained by quadratic models, confidence intervals for estimating milk yield based on preweaning ADG were wide. For example, a calf with preweaning ADG of $0.5 \mathrm{~kg} / \mathrm{d}$ was predicted to produce between 5,000 and $12,500 \mathrm{~kg}$ of milk in the first lactation. It may be possible to improve milk production by increasing preweaning growth, but actual coefficients reported here should be applied with caution, because they account for less than $3 \%$ of the variation in observed response.

\section{CONCLUSIONS}

The majority $(98 \%)$ of variation in all response variables was explained by study, indicating that other aspects of farm management have more of an effect on first-lactation performance than altering preweaning nutrition and growth. Models based on 21 treatment groups in 9 studies relating preweaned calf nutrition and growth to 305-d milk, fat, and protein yields in the first lactation indicated that preweaning growth rate and intake of milk or milk replacer and calf starter can enhance the effects of good management postweaning, but account for less than $3 \%$ of the variation in 
responses observed. Dry matter intake from liquid and starter diets synergistically increased first-lactation performance such that feeding an additional $100 \mathrm{~g} / \mathrm{d}$ of liquid DM projected a $66.2 \mathrm{-kg}$ increase in first-lactation milk yield. However, if combined with starter DMI, feeding an additional $100 \mathrm{~g} / \mathrm{d}$ of liquid DM projected a 138.5-kg increase in milk yield. Preweaning ADG between 0.3 and $0.5 \mathrm{~kg} / \mathrm{d}$ had minimal effects on lactation performance, but the effect of growth rate increased as ADG rose from 0.5 to $0.9 \mathrm{~kg} / \mathrm{d}$. This analysis was limited by the range of observations in the included studies and by the overwhelming influence of study compared with variables of interest; exact coefficients reported here should be applied with caution. Although exact lactation response may vary, provision of adequate nutrients from liquid and solid feeds and maintaining ADG above $0.5 \mathrm{~kg} / \mathrm{d}$ can enhance first-lactation performance of heifers when combined with proper postweaning management.

\section{ACKNOWLEDGMENTS}

The authors thank Penn State colleagues Brenda Heinrichs for her assistance with data analysis and model selection and Chad Dechow for preparing data from individual studies for analysis.

\section{REFERENCES}

Aho, K., D. Derryberry, and T. Peterson. 2014. Model selection for ecologists: The worldviews of AIC and BIC. Ecology 95:631-636.

Anderson, D. R., K. P. Burnham, and W. L. Thompson. 2000. Null hypothesis testing: Problems, prevalence, and an alternative. J. Wildl. Manage. 64:912-923.

Bach, A. 2012. Ruminant nutrition symposium: Optimizing performance of the offspring: Nourishing and managing the dam and postnatal calf for optimal lactation, reproduction, and immunity. J. Anim. Sci. 90:1835-1845.

Bach, A., M. Terré, and A. Pinto. 2013. Performance and health responses of dairy calves offered different milk replacer allowances. J. Dairy Sci. 96:7790-7797.

Bar-Peled, U., B. Robinzon, E. Maltz, H. Tagari, Y. Folman, I. Bruckental, H. Voet, H. Gacitua, and A. R. Lehrer. 1997. Increased weight gain and effects on production parameters of Holstein heifer calves that were allowed to suckle from birth to six weeks of age. J. Dairy Sci. 80:2523-2528.

Brown, E. G., M. J. VandeHaar, K. M. Daniels, J. S. Liesman, L. T. Chapin, J. W. Forrest, R. M. Akers, R. E. Pearson, and M. S. Weber Nielsen. 2005. Effect of increasing energy and protein intake on mammary development in heifer calves. J. Dairy Sci. 88:595-603.

Burnham, K. P., and D. R. Anderson. 2001. Kullback-Leibler information as a basis for strong inference in ecological studies. Wildl. Res. 28:111-119.

Castells, L., A. Bach, and M. Terré. 2015. Short- and long-term effects of forage supplementation of calves during the preweaning period on performance, reproduction, and milk yield at first lactation. J. Dairy Sci. 98:4748-4753.

Council on Dairy Cattle Breeding. 2015. Public database query: Derive standardized cow records from actual records entered. Accessed Aug. 27, 2015. https://www.cdcb.us/cgi-bin/general/Qpublic/do. Q.cgi?qname $=$ getageadj\&single.
Cowles, K. E., R. A. White, N. L. Whitehouse, and P. S. Erickson. 2006. Growth characteristics of calves fed an intensified milk replacer regimen with additional lactoferrin. J. Dairy Sci. 89:48354845 .

Davis, C. L., and J. K. Drackley. 1998. The Development, Nutrition, and Management of the Young Calf. Iowa State University Press, Ames.

Davis Rinker, L. E., M. J. VandeHaar, C. A. Wolf, J. S. Liesman, L. T. Chapin, and M. S. Weber Nielsen. 2011. Effect of intensified feeding of heifer calves on growth, pubertal age, calving age, milk yield, and economics. J. Dairy Sci. 94:3554-3567.

Foote, M. R., B. J. Nonnecke, D. C. Beitz, and W. R. Waters. 2007. High growth rate fails to enhance adaptive immune responses of neonatal calves and is associated with reduced lymphocyte viability. J. Dairy Sci. 90:404-417.

Gaines, W. L., and F. A. Davidson. 1923. Relation between percentage fat content and yield of milk: correction of milk yield for fat content. Univ. Illinois Agric. Exp. Station Bull. 245. Univ. of Illinois, Urbana.

Heinrichs, A. J., and B. S. Heinrichs. 2011. A prospective study of calf factors affecting first-lactation and lifetime milk production and age of cows when removed from the herd. J. Dairy Sci. 94:336-341.

Hill, S. R., B. A. Hopkins, S. Davidson, S. M. Bolt, D. E. Diaz, C. Brownie, T. Brown, G. B. Huntington, and L. W. Whitlow. 2009 The addition of cottonseed hulls to the starter and supplementation of live yeast or mannanoligosaccharide in the milk for young calves. J. Dairy Sci. 92:790-798.

Jasper, J., and D. M. Weary. 2002. Effects of ad libitum milk intake on dairy calves. J. Dairy Sci. 85:3054-3058.

Khan, M. A., A. Bach, D. M. Weary, and M. A. G. von Keyserlingk. 2016. Invited review: Transitioning from milk to solid feed in dairy heifers. J. Dairy Sci. 99:885-902.

Khan, M. A., H. J. Lee, W. S. Lee, H. S. Kim, S. B. Kim, K. S. Ki, J. K. Ha, H. G. Lee, and Y. J. Choi. 2007. Pre- and postweaning performance of Holstein female calves fed milk through step-down and conventional methods. J. Dairy Sci. 90:876-885.

Khan, M. A., H. J. Lee, W. S. Lee, H. S. Kim, S. B. Kim, S. B. Park, K. S. Baek, J. K. Ha, and Y. J. Choi. 2008. Starch source evaluation in calf starter: II. Ruminal parameters, rumen development, nutrient digestibilities, and nitrogen utilization in Holstein calves. J. Dairy Sci. 91:1140-1149.

Kiezebrink, D. J., A. M. Edwards, T. C. Wright, J. P. Cant, and V. R. Osborne. 2015. Effect of enhanced whole-milk feeding in calves on subsequent first-lactation performance. J. Dairy Sci. 98:349-356.

Lohakare, J. D., K. H. Sudekum, and A. K. Pattanaik. 2012. Nutrition-induced changes of growth from birth to first calving and its impact on mammary development and first-lactation milk yield in dairy heifers: A review. Asian-australas J. Anim. Sci. 25:13381350.

Margerison, J. K., A. D. J. Robarts, and G. W. Reynolds. 2013. The effect of increasing the nutrient and amino acid concentration of milk diets on dairy heifer individual feed intake, growth, development, and lactation performance. J. Dairy Sci. 96:6539-6549.

Moallem, U., D. Werner, H. Lehrer, M. Zachut, L. Livshitz, S. Yakoby, and A. Shamay. 2010. Long-term effects of ad libitum whole milk prior to weaning and prepubertal protein supplementation on skeletal growth rate and first-lactation milk production. J. Dairy Sci. 93:2639-2650.

Morrison, S. J., H. C. F. Wicks, R. J. Fallon, J. Twigge, L. E. R. Dawson, A. R. G. Wylie, and A. F. Carson. 2009. Effects of feeding level and protein content of milk replacer on the performance of dairy herd replacements. Animal 3:1570-1579.

Raeth-Knight, M., H. Chester-Jones, S. Hayes, J. Linn, R. Larson, D. Ziegler, B. Ziegler, and N. Broadwater. 2009. Impact of conventional or intensive milk replacer programs on Holstein heifer performance through six months of age and during first lactation. J. Dairy Sci. 92:799-809.

Sejrsen, K., S. Purup, M. Vestergaard, and J. Foldager. 2000. High body weight gain and reduced bovine mammary growth: Physiological basis and implications for milk yield potential. Domest. Anim. Endocrinol. 19:93-104. 
Shamay, A., D. Werner, U. Moallem, H. Barash, and I. Bruckental 2005. Effect of nursing management and skeletal size at weaning on puberty, skeletal growth rate, and milk production during first lactation of dairy heifers. J. Dairy Sci. 88:1460-1469.

Soberon, F., E. Raffrenato, R. W. Everett, and M. E. Van Amburgh. 2012. Preweaning milk replacer intake and effects on long-term productivity of dairy calves. J. Dairy Sci. 95:783-793.

Soberon, F., and M. E. Van Amburgh. 2013. Lactation biology symposium: The effect of nutrient intake from milk or milk replacer of preweaned dairy calves on lactation milk yield as adults: A metaanalysis of current data. J. Anim. Sci. 91:706-712.

St-Pierre, N. R. 2001. Invited review: Integrating quantitative findings from multiple studies using mixed model methodology. J. Dairy Sci. 84:741-755.

Stamey, J. A., N. A. Janovick, A. F. Kertz, and J. K. Drackley. 2012. Influence of starter protein content on growth of dairy calves in an enhanced early nutrition program. J. Dairy Sci. 95:3327-3336.
Sweeney, B. C., J. Rushen, D. M. Weary, and A. M. de Passillé. 2010 Duration of weaning, starter intake, and weight gain of dairy calves fed large amounts of milk. J. Dairy Sci. 93:148-152.

Terré, M., C. Tejero, and A. Bach. 2009. Long-term effects on heifer performance of an enhanced-growth feeding programme applied during the preweaning period. J. Dairy Res. 76:331-339.

Van Vleck, L. D., and M. C. Dong. 1988. Genetic (co) variances for milk, fat, and protein yield in Holsteins using an animal model. J. Dairy Sci. 71:3040-3046.

Zanton, G. I., and A. J. Heinrichs. 2005. Meta-analysis to assess effect of prepubertal average daily gain of Holstein heifers on firstlactation production. J. Dairy Sci. 88:3860-3867. 